\title{
Addition of Zinc, Manganese, and Iron to Growth Media Triggers Antibiotic Production in Bacterial Isolates From the Lower Atmosphere
}

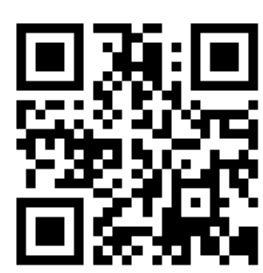

\author{
Quinn L. Washburn ${ }^{1 *}$, Savannah Spradlin ${ }^{1,2} \&$ Carolyn F. Weber ${ }^{1}$
}

With the growing number of antibiotic-resistant pathogens, there is a need for new antibiotics. Bacteria within the order Actinomycetales produce the majority of known antibiotic compounds but harbor cryptic secondary metabolic pathways that likely produce thousands more antibiotics awaiting discovery. This has recently renewed interests in bioprospecting for novel Actinomycetales in underexplored environments, such as the lower atmosphere, and activating cryptic secondary metabolic pathways in previously characterized members of this order. Many antibiotic-producing Actinomycetales have complex metabolic interactions with trace metals (such as iron, zinc, and manganese); adding these metals to bacterial growth media may trigger antibiotic production, which could lead to the discovery of novel drugs that may otherwise be overlooked during screening in the absence of such metals. To test this hypothesis, a collection of bacterial isolates, composed primarily of taxa within the order Actinomycetales, was obtained from the lower atmosphere. In support of our hypothesis, we found that several isolates produced antibiotics in the presence of trace metals, but not in their absence. Further investigation is required to identify the compounds being produced, but our results suggest that adding trace metals to growth media during high-throughput screening efforts may be a fruitful approach for identifying antibiotic-producing bacteria in large culture collections.

\section{INTRODUCTION}

According to the World Health Organization (2015), pathogens are becoming more antibiotic-resistant than ever before, which is a problem caused and exacerbated by the overuse and misuse of existing antibiotics. As a result, there is a desperate need for novel antibiotics, but the approval rate of clinical antibiotics continues to decline (Donadio, Maffioli, Monciardini, Sosio, \& Jabes, 2010). The order Actinomycetales within the phylum Actinobacteria, includes the genus Streptomyces, which produces two-thirds of known antibiotics (Barka et al., 2016; Watve, Tickoo, Jog, \& Bhole, 2001). This genus is predicted to produce 150,000 to almost 300,000 antimicrobial compounds still awaiting discovery (Watve et al., 2001). Therefore, predictions about the next source of novel

${ }^{1}$ Idaho State University, Department of Biological Sciences, 921 South 8th Avenue, Stop 8007, Pocatello Idaho, 83209

${ }^{2}$ Idaho State University, Department of Chemistry, 921 South 8th Avenue, Stop 8023, Pocatello Idaho, 83209

*To whom correspondence should be addressed: quinnwashb@gmail.com

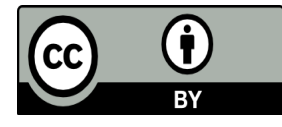

Except where otherwise noted, this work is licensed under https://creativecommons.org/licenses/by/4.0/

doi:10.22186/jyi.32.2.7-11 antibiotics often point to Actinomycetales (Bérdy, 2012; Goodfellow \& Fiedler, 2010).

Goodfellow \& Fiedler (2010) stated that by using selective techniques, such as sampling from understudied and extreme environments, novel Actinobacteria may be discovered. One such environment, is the lower atmosphere (Weber and Werth, 2015), which is defined by as the first $20 \mathrm{~km}$ above ground level (Womack, Bohannan, \& Green 2010). A multitude of both culture-dependent and culture-independent studies demonstrate that Actinobacteria are an omnipresent component of the aerial environment (Bowers et al., 2011; Fahlgren, Hagström, Nilsson, \& Zweifel, 2010; Polymenakou, 2012; Shaffer \& Lighthart, 1997; Weber \& Werth, 2015). The lower atmosphere has several distinct advantages in the search for novel Actinomycetales. The lower atmosphere is a highly variable environment (Fahlgren et al., 2010) with dramatically oscillating temperatures $\left(-56^{\circ} \mathrm{C}\right.$ to $\left.15^{\circ} \mathrm{C}\right)$, low relative humidity and high levels of ultraviolet radiation (Womack, Bohannan, $\&$ Green, 2010). These conditions may select for Actinomycetales over faster-growing bacterial taxa, such as many Proteobacteria (Weber \& Werth, 2015). Exploring the lower atmosphere, given its potential to harbor antibiotic-producing bacteria, with selective cultivation methods may lead to the discovery of novel species and antibiotics. While not as commonly studied for their antibiotic-producing capabilities, Bacillus is another genus of bacteria that contains antibiotic-producing members and is commonly found in the lower atmosphere (Athukorala, Dilantha Fernando, \& Rashid, 2009; Fahlgren et al., 2010; Shaffer \& Lighthart, 1997).

Another approach to discover novel antibiotic compounds is to place a single organism under a wide array of culture conditions 
in an attempt to activate cryptic metabolic pathways that may produce uncharacterized metabolites with antibiotic properties known as the 'One-Strain-Many-Compounds' approach (Bode, Bethe, Höfs, \& Zeeck, 2002). This method focuses on elucidating the up to 50 different pathways that have been found in a single Streptomyces strain, instead of screening massive numbers of isolates (Barka et al., 2016) in one set of conditions. The disadvantage of the latter approach is that it frequently results in the disposal of isolates, which do not produce antibiotic compounds under the one set of conditions tested (Bode et al., 2002). Culturing an isolate under altered conditions has been shown to encourage the production of antibiotics. Modifications of growth media that have been found to elicit the expression of secondary metabolite pathways include metals and amino acid additions (notably tryptophan; Palazzotto et al., 2015), as well as varied phosphate concentrations, carbon sources, nitrogen sources, and $\mathrm{pH}$, to name a few (Bode et al., 2002; Iwai \& Ōmura, 1982; Marwick, Wright, \& Burgess, 1999; Weinberg, 1990).

Along these lines, amending growth media with trace metals is possibly a fruitful approach for activating cryptic secondary metabolic pathways, as trace metals are often required for the expression of secondary metabolite pathways (Haferburg et al., 2009; Huck, Porter, \& Bushell, 1991; Iwai \& Ōmura, 1982; Weinberg, 1990). Ochi and Hosaka (2013) indicated that rare earth metals and trace metals, notably manganese, zinc and iron may trigger the production of various secondary metabolic pathways. Actinobacteria have complex metabolic interactions with metals (Abbas \& Edwards, 1989; Abbas \& Edwards, 1990; Haferberg \& Kothe, 2007; Paul \& Banerjee 1983; Pettit, 2011). For instance, Yamasaki, Furuya, \& Matsuyama (1998) showed that the impact of a metal ion on an isolate's antibiotic production varies depending on the anionic species to which it is associated. Additionally, a single trace metal may inhibit antibiotic production in some cases, but encourage production in others, making trace metals potentially useful in the discovery of novel antibiotics (Abbas \& Edwards, 1989; Abbas \& Edwards, 1990; Bundale et al., 2015; Huck et al., 1991; Iwai \& Ōmura, 1982; Weinberg, 1990).

In this study, the impact of amending media with three different metals (iron, manganese, and zinc) on the ability of bacterial isolates to produce antibiotics was examined. Isolates were obtained from the lower atmosphere and their ability inhibit the growth of Gram-positive and Gram-negative bacteria was assessed.

\section{MATERIALS AND METHODS}

\section{Air Sampling and Selection of Isolates}

Air samples (180L) were collected onto $90 \mathrm{~mm}$ petri plates containing Tryptic Soy Agar (TSA; Honeywell Specialty Chemicals, Seelze, Germany) amended with $50 \mu \mathrm{g} / \mathrm{mL}$ cycloheximide (TSAC), using a SAS SUPER 180 (Bioscience International, Rockville, $\mathrm{MD}$ ) on the roof of the Gale Life Science Building on the Idaho State University campus (Pocatello, ID, USA). Plates were incubated at room temperature until Actinomycetales-like morpholo- gies developed (approximately 5 days). Colonies with unique morphologies, several of which were Bacillus-like, were selected for isolation and purification.

\section{Inhibition Assays}

After several streaks for purification, eight isolates of Actinomycetales-like and Bacillus-like morphologies and twelve isolates identified using the 16S rRNA gene from air samples collected between 2013 and 2015 were plated onto $60 \mathrm{~mm}$ x $15 \mathrm{~mm}$ petri dishes containing Luria Broth (LB; Thermo Fisher Scientific, Waltham, MA), King's B (KB; Coldspring Harbor, 2009), tryptic soy agar (TSA), TSA with cycloheximide (TSA-C), TSA with $10 \mathrm{mM}\left(\mathrm{NH}_{4}\right)_{5} \mathrm{Fe}\left(\mathrm{C}_{6} \mathrm{H}_{4} \mathrm{O}_{7}\right)_{2}$ (TSA-Fe), TSA with $10 \mathrm{mM} \mathrm{MnCl}_{2}$ (TSA-Mn), and TSA with $10 \mathrm{mM} \mathrm{ZnSO}_{4} \bullet 7 \mathrm{H}_{2} \mathrm{O}$ (TSA-Zn), KB with $10 \mathrm{mM}\left(\mathrm{NH}_{4}\right)_{5} \mathrm{Fe}\left(\mathrm{C}_{6} \mathrm{H}_{4} \mathrm{O}_{7}\right)_{2}(\mathrm{~KB}-\mathrm{Fe}), \mathrm{KB}$ with $10 \mathrm{mM} \mathrm{MnCl}_{2}$ (KB-Mn), and $\mathrm{KB}$ with $10 \mathrm{mM} \mathrm{ZnSO}_{4} \cdot 7 \mathrm{H}_{2} \mathrm{O}$ (KB-Zn). The isolates were grown for one week at room temperature and then overlaid with molten LB agar amended with $1 \mu \mathrm{L} / \mathrm{mL}$ of TSA broth containing either $S$. aureus or E. coli with average optical densities (measured at $600 \mathrm{~nm}$ ) of 1.885 and 1.648 , respectively. Plates were incubated and monitored for zones of clearance around the isolates for seven days, indicating inhibition of S. aureus or E. coli growth.

\section{Determination of Airborne Isolates' Taxonomy}

The twelve isolates utilized in the second set of inhibition assays were taxonomically identified by sequencing their 16S rRNA genes. DNA was extracted from isolates using the UltraClean Microbial DNA Isolation Kit (Mo Bio, Carlsbad, CA) following the manufacturer's protocol, except only $25 \mu \mathrm{L}$ of the kit's solution MD5 rather than $50 \mu \mathrm{L}$ was used in the final DNA elution step. The 16S rRNA gene was amplified using a Mastercycler Pro S (Eppendorf, Hamburg, Germany) in $20 \mu \mathrm{L}$ reaction volumes containing: 1x buffer solution, $200 \mu \mathrm{M}$ dNTPs, $3 \%$ DMSO, $0.5 \mu \mathrm{M} 27 \mathrm{~F}$ primer, $0.5 \mu \mathrm{M}$ 1492R primer, $0.03 \mathrm{U}_{\mu} \mathrm{L}^{-1}$ Phusion High-Fidelity DNA Polymerase (Thermo Fisher Scientific, Waltman, MA) using universal 27F 5'-AGAGTTTGATCMTGGCTCAG-3' and 1492R 5'-TACGGYTACCTTGTTACGACTT-3' primers using the following PCR conditions: initial denaturation at $98^{\circ} \mathrm{C}$ for 30 seconds; thirty cycles of $98^{\circ} \mathrm{C}$ for 30 seconds, $64^{\circ} \mathrm{C}$ for 45 seconds, $72^{\circ} \mathrm{C}$ for 30 seconds; final extension at $72^{\circ} \mathrm{C}$ for five minutes. Amplicons were purified using the MinElute PCR Purification Kit (QIAGEN, Hilden, Germany) and delivered to the Idaho State University Molecular Research Core Facility (Pocatello, ID, USA) for bidirectional sequencing. Contigs were formed from the bidirectional sequence reads using Sequencher version 5.1 (Gene Codes Corporation, Ann Arbor, MI). Sequences were taxonomically identified using the Basic Local Alignment Search Tool (BLAST).

\section{RESULTS}

The impact of four different complex media types with and without three different trace metal amendments on the ability of isolates to inhibit the growth of E. coli and S. aureus was tested. Antibiotic production was observed more frequently in media types 
containing trace metal amendments than in media lacking such amendments (Table 1). Only three of the eight isolates inhibited $S$. aureus growth on any of the complex medias, while seven of the eight isolates inhibited the growth of $S$. aureus on at least one of the trace metal-amended mediums. Many isolates failed to grow on TSA during the E. coli inhibition assay. Therefore, the impact of trace metals on the production of antibiotics that were effective against Gram-negative bacteria is unclear.

The inhibitory activity of isolate $31 \mathrm{RC} 1$ is of particular interest. This isolate only inhibited the growth of E. coli on TSA media. However, when iron and manganese were added, it became effective only to $S$. aureus. This indicates that the addition of metals may result in the production of completely different inhibitory compounds.

Eleven of the twelve isolates utilized in the second experiment were genera within Actinomycetales (Streptomyces, Nocardia, Rhodococcus) representing seven different species, and one isolate was a Staphylococcus spp. (Table 2). Inhibition assays were performed on KB media, and $\mathrm{KB}$ media amended with $10 \mathrm{mM}$ of iron, zinc, or manganese (Table 2). None of the isolates inhibited E. coli on any media types. When the isolates were assayed against $S$. aureus, isolates that were identified as the same strain had distinct antibiotic-producing behaviors when trace metals were added. This was the most notable for the three isolates identified as Streptomyces pratensis, which had different inhibition capabilities, but all were able to inhibit $S$. aureus with the addition of zinc to the media. In some instances, metals improved antibiotic production capabilities especially in isolate $4 \mathrm{oA}^{2}$, where

the addition of zinc alone resulted in inhibition. For every isolate that inhibited $S$. aureus on KB, inhibition was also observed on at least one medium with a metal amendment; while isolate QLW 21 produced no antibiotic on the zinc-amended media, it still produced antibiotics on manganese-amended and iron-amended media. Furthermore, replicate assay plates using the same isolate showed inconsistencies in inhibition such as in the case of isolate QAS 5, which inhibited $S$. aureus on manganese-amended media on only one of the four replicate assay plates.

\section{DISCUSSION}

With the need for novel antibiotics, there is renewed interest in screening large collections of bacteria to identify antibioticproducing cultures. There is also renewed interest in identifying alternative sets of culturing conditions to trigger the production of uncharacterized secondary metabolites. By restricting screening assays to one culture condition, bacterial isolates of interest may be prematurely removed from further study. Using an array of conditions for initial antibiotic screens will likely facilitate the discovery of new antibiotics. Our data supports the hypothesis that adding trace metals to bacterial growth media may be an effective way to activate cryptic, secondary metabolite-producing pathways (Haferberg \& Kothe, 2013).

Few metal-facilitated, antibiotic producing pathways have been studied in enough detail to determine the exact role that the metal ions play. It was hypothesized that metal ions are essential cofactors in antibiotic pathways (Iwai \& Ōmura, 1982). The well-studied antibiotic production of actinorhodin in $S$. coelicolor A3(2) found that the addition of zinc to media may have allowed antibiotic producing, zinc-dependent enzymes to function when most intracellular zinc would otherwise be unavailable near the end of the exponential phase, thus predicting that the zinc affects translation directly and indirectly through feedback (Hesketh, Kock, Mootien, \& Bibb, 2009).

Our results add to the growing collection of data that indicates that strain-to-strain variation in antibiotic production capacity is large, and culture identification at the species-level is not a reliable predictor of an organism's ability to produce compounds with antibiotic properties. Schmidt et al. (2009) observed that bacterial isolates identified as the same species, respond to nickel using dif-

Table 1. Inhibition of $\boldsymbol{E}$. coli and $\boldsymbol{S}$. aureus by isolates. + indicates inhibition of Gram-positive, - indicates inhibition of Gram-negative, a blank space indicates there was no inhibition, ? indicates the results were not conclusive, and X indicates the isolate did not grow.

\begin{tabular}{|c|c|c|c|c|c|c|c|c|c|c|c|c|c|c|}
\hline \multirow[b]{2}{*}{ Isolate } & \multicolumn{7}{|c|}{ S. aureus } & \multicolumn{7}{|c|}{ E. coli } \\
\hline & TSA & TSA-C & $\mathrm{LB}$ & $\mathrm{KB}$ & TSA-Fe & TSA-Mn & TSA-Zn & TSA & TSA-C & LB & $\mathrm{KB}$ & TSA-Fe & TSA-Mn & TSA-Zn \\
\hline $31 \mathrm{RC} 2$ & + & $X$ & & & + & + & + & $?$ & & & & & & \\
\hline $17 S S 2$ & $?$ & & + & & & + & & $\mathrm{X}$ & $\mathrm{X}$ & & & - & - & \\
\hline 6RCl & + & + & & & + & + & + & & & & & & & \\
\hline 7JW4 & & & & & & $?$ & & $X$ & $\mathrm{X}$ & $\mathrm{X}$ & & & - & \\
\hline $17 S S 3$ & & & & & + & & $?$ & $?$ & $?$ & & & & & $?$ \\
\hline 7JW5 & & $X$ & & & & $X$ & + & $?$ & $X$ & & & $X$ & $X$ & $X$ \\
\hline 26JW2 & & & & & & + & + & $?$ & & & & & & \\
\hline $31 \mathrm{RCl}$ & & & $?$ & $?$ & + & + & $?$ & - & $?$ & & & & & \\
\hline
\end{tabular}


Table 2. Inhibition of $S$. aureus by 16s rRNA gene identified isolates. ++ indicates major inhibition, + indicates inhibition, $(+)$ indicates mild inhibition, and - indicates no inhibition.

\begin{tabular}{|c|c|c|c|c|c|}
\hline Isolate & KB & KB-Mn & KB-ZN & KB-Fe & BLAST Result \\
\hline 111513air5 &,,,+--- & $\begin{array}{l}++,++,+,- \\
(+),(+)\end{array}$ & $\begin{array}{l}++,++,+,+ \\
+,(+)\end{array}$ & $+,(+),(+),(+)$ & $\begin{array}{l}\text { Streptomyces griseorubens strain JSD-1 genomic } \\
\text { scaffold scaffold1, whole genome } \\
\text { shotgun sequence } \\
\text { Streptomyces griseorubens strain JSD-1 genomic } \\
\text { scaffold scaffold1, whole genome } \\
\text { shotgun sequence }\end{array}$ \\
\hline $\begin{array}{l}\text { QAS 6 } \\
\text { 111513air2 }\end{array}$ &,-- & $\begin{array}{l}-,- \\
(+),-\end{array}$ & $\begin{array}{l}-,- \\
-,-\end{array}$ & $\begin{array}{l}-,- \\
-,-\end{array}$ & $\begin{array}{l}\text { Streptomyces coelicolor A3(2) chromosome, } \\
\text { complete genome } \\
\text { Streptomyces coelicolor A3(2) chromosome, } \\
\text { complete genome }\end{array}$ \\
\hline $\begin{array}{l}\text { QAS } 5 \\
40 A^{2} \\
\text { QAS } 2\end{array}$ & $\begin{array}{l}+,+,(+),- \\
-,- \\
(+),-\end{array}$ & $\begin{array}{l}+,-,-,- \\
-,- \\
+,-\end{array}$ & $\begin{array}{l}+,(+),(+),(+) \\
(+),(+) \\
+,+\end{array}$ & $\begin{array}{l}-,-,-,- \\
-,- \\
(+),-\end{array}$ & $\begin{array}{l}\text { Streptomyces pratensis ATCC } 33331 \text {, } \\
\text { complete genome } \\
\text { Streptomyces pratensis ATCC } 33331 \text {, } \\
\text { complete genome } \\
\text { Streptomyces pratensis ATCC } 33331 \text {, } \\
\text { complete genome }\end{array}$ \\
\hline 111013 air4 &,++++ &,+++ &,+++ &,++ & Streptomyces scabiei 87.22 complete genome \\
\hline $4 \mathrm{oC}^{2}$ & $(+),(+)$ &,+- &,-- & $(+),-$ & $\begin{array}{l}\text { Streptomyces chartreusis NRRL } 12338 \text { genomic } \\
\text { scaffold } 12338 \text { _Doro1_scaffold4, whole genome } \\
\text { shotgun sequence }\end{array}$ \\
\hline QLW 21 &,+++++ &,+++ &,-- &,+++ & $\begin{array}{l}\text { Nocardia exalbida NBRC } 100660 \text { DNA, contig: } \\
\text { NE1_con28, whole genome shotgun sequence }\end{array}$ \\
\hline 3PA &,-- &,-- &,-- &,-- & $\begin{array}{l}\text { Rhodococcus fascians A44A contig24, whole } \\
\text { genome shotgun sequence }\end{array}$ \\
\hline $\begin{array}{l}\text { KR } 1 \\
\text { 100L-KR1 }\end{array}$ &,-- &,-- &,-- &,-- & $\begin{array}{l}\text { Staphylococcus hominis hominis } \mathrm{C} 80 \\
\text { genomic scaffold supercont } 1.5 \text {, whole genome } \\
\text { shotgun sequence }\end{array}$ \\
\hline
\end{tabular}

ferent mechanisms. This is perhaps a result of genetic mutations affecting antibiotic production akin to those examined by Higo, Hara, Horinouchi and Ohnishi (2012) or plasmid acquisition or loss. For instance, metabolic pathways encoding the production of molecules such as methylenomycin A have been found on transmittable plasmids (Wright \& Hopwood, 1976).

Inconsistencies in the antibiotic production between inhibition assay replicates of the same isolate may be a result of the developmental stage reached by the isolate at the time of the assay. The stage of development triggers antibiotic production; generally occurring at the end of the exponential phase (Abbas \& Edwards, 1990; Hesketh et al., 2009; Weinberg, 1990), but the mechanism is not entirely understood (Bibb, 2005). Nonetheless, trace metals, even if not the only determining factor, certainly appear to encourage antibiotic production and their addition to bacterial growth media should be considered when screening large collections of isolates or even single organisms for their ability to produce novel antibiotics.

\section{CONCLUSIONS}

The lower atmosphere is an accessible source of antibiotic-producing bacteria that should be further studied. Trace metals can trigger the production of antibiotics and should be included while screening isolates for antibiotic activity. Using replicate assay plates of isolates should also be considered during screening, as isolates inconsistently produced antibiotics. Although further study of this phenomenon is needed, it may be the result of the stage of development reached by the test colonies. Lastly, even if a bacterial strain is determined to be common and "well-studied" based on the identity of its $16 \mathrm{~S}$ rRNA gene sequence, incorporating trace metal amendments into the 'one-strain-many-compounds' approach may result in the discovery of novel antibiotics. 


\section{ACKNOWLEDGEMENTS}

We thank Abdullah Aljadi, Rachel Clinger, Naomi Veloso and Sora Matsunaga for their work on this study via their participation in the AMOEBA program at Idaho State University (National Science Foundation (NSF DUE 1140286; J.P. Hill, PI), and Jason T. Werth for technical support. Funding for this project was provided by a Dimensions of Biodiversity grant from the NSF (NSF DEB 1241069; C.F. Weber, PI).

\section{REFERENCES}

Abbas, A. \& Edwards, C. (1989). Effects of metals on a range Streptomyces species. Appl. Environ. Microbiol. 55(8): 2030-2035.

Abbas, A. \& Edwards, C. (1990). Effects of metals on Streptomyces coelicolor growth and Actinorhodin production. Appl. Environ. Microbiol. 56(3): 675680 .

Athukorala, S. N. P., Dilantha Fernando, W. G., \& Rashid, K. Y. (2009). Identification of antifungal antibiotics of Bacillus species isolated from different microhabitats using polymerase chain reaction and MALDI-TOF mass spectrometry. Can. J. Microbiol. 55: 1021-1032. doi:10.1139/W09-067

Barka E. A., Vatsa, P., Sanchez, L., Gaveau-Vaillant, N., Jacquard, C., Klenk, H-P., Clément, C., Ouhdouch, Y., \& van Wezel, G. P. (2016). Taxonomy, physiology, and natural products of Actinobacteria. Micobiol. Mol. Biol. Rev. 80(1): 1-43. 25 November 2015 doi:10.1128/MMBR.00019-15.

Bérdy, J. (2012). Thoughts and facts about antibiotics: Where we are now and where we are heading. J. Antibiot. 65: 385-395. doi:10.1038/ja.2012.27

Bibb, M. J., (2005). Regulation of secondary metabolism in Streptomycetes. Curr. Opin. Microbiol. 8: 208-215. doi: 10.1016/j.mib.2005.02.016

Bode, H. B., Bethe, B., Höfs, R., \& Zeeck, A. (2002). Big effects from small changes: Possible ways to explore nature's chemical diversity. Chem. Bio. Chem. 3: 619-627. doi:10.1002/1439-7633(20020703)3:7<619::AIDCBIC619>3.0.CO;2-9

Bowers, R. M., Sullivan, A. P., Costello, E. K., Collett, J. L. Jr., Knight, R., \& Fierer, N. (2011). Sources of bacteria in outdoor air across cities in the Midwestern United States. Appl., Environ. Microbiol. 77(18): 6350-6356. doi:10.1128/AEM.05498-11

Bundale, S., Begde, D., Nahikkar, N., Kadam, T., \& Upadhyay, A. (2015). Optimization of culture conditions for production of bioactive metabolites by Streptomyces spp. Isolated form soil. Adv. Microbiol. 5: 441-451. doi:10.4236/ aim. 2015.56045

Donadio, S., Maffioli, S., Monciardini, P., Sosio, M., \& Jabes, D. (2010). Antibiotic discovery in the twenty-first century: current trends and future perspectives. J. Antibiot. 63:423-430. doi:10.1038/ja.2010.62

Fahlgren C., Hagström, A., Nilsson, D., \& Zweifel U. L. (2010). Annual variations in the diversity, viability, and origin of airborne bacteria. Appl. Environ. Micobiol. 76(9): 3015-3025. doi:10.1128/AEM.02092-09.

Goodfellow, M., \& Fiedler, H-P. (2010). A guide to successful bioprospecting: informed by actinobacterial systematics. Antonie van Leeuwenhoek. 98(2): 119-142. doi:10.1007/s10482-010-9460-2

Haferburg, G., \& Kothe, E. (2007). Microbes and metals: interactions in the environment. J. Basic Microbiol. 47: 453-467. doi:10.1002/jobm.200700275

Haferburg, G., Groth, I., Möllmann, U., Kothe, E., \& Sattler, I. (2009). Arousing sleeping genes: shifts in secondary metabolism of metal tolerant Actinobacteria under conditions of heavy metal stress. Biometals 22: 225-234. doi:10.1007/s10534-008-9157-4

Haferburg, G., \& Kothe, E. (2013). Activation of silent genes in actinobacteria by exploiting metal stress. In Amoroso, M. J., Benimeli, C. S., \& Cuozzo, S. A. (Eds.), actinobacteria: application in bioremediation and production of industrial enzymes (56-73). Boca Raton, FL: CRC Press.

Hesketh, A., Kock, H., Mootien, S., \& Bibb, M. (2009). The role of absC, a novel regulatory gene for secondary metabolism, in zinc-dependent antibiotic production in Streptomyces coelicolor A3(2). 74(6): 1427-1444. doi:10.1111/ j.1365-2958.2009.06941.x

Higo, A., Hara, H., Horinouchi, S., \& Ohnishi Y. (2012). Genome-wide distribution of AdpA, a global regulator for secondary metabolism and morphological differentiation in Streptomyces, revealed the extent and complexity of the AdpA regulatory network. DNA Res. 19: 259-273. doi:10.1093/dnares/ dss010

Huck, T. A., Porter, N., \& Bushell, M. E. (1991). Positive selection of antibiotic producing soil isolates. J. Gen. Microbiol. 137: 2321-2329.

Iwai, Y., \& Ōmura, S. (1982). Culture conditions for screening of new antibiotics. J. Antibiot. 35(2): 123-141.

King's B medium. (2009). Cold Spring Harbor Protocols. doi:10.1101/pdb. rec11326

Schmidt, A., Haferburg G., Schmidt, A., Lischke, U., Merten, D., Ghergel, F., Büchel, G., \& Kothe, E. (2009). Heavy metal resistance to the extreme: Streptomyces strains from a former uranium mining area. Chem. Erde. Geochem. 60(2): 35-44. doi:10.1016/j.chemer.2007.11.002

Shaffer, B. T., \& Lighthart B. (1997). Survey of culturable airborne bacteria at four diverse locations in Oregon: urban, rural, forest, and coastal. 2: 167-177. doi: $10.1007 / \mathrm{s} 002489900046$

Marwick, J. D., Wright, P. C., \& Burgess, J. G. (1999). Bioprocess intensification for production of novel marine bacterial antibiotics through bioreactor operation and design. Mar. Biotechnol. 1: 495-507. doi:10.1007/PL00011806

Ochi, K., \& Hosaka, T. (2013). New strategies for drug discovery: activation of silent or weakly expressed microbial gene clusters. Appl. Microbiol. Biotechnol. 97(1): 87-98. doi:10.1007/s00253-012-4551-9

Palazzotto, E., Renzone, G., Fontana, P., Botta, L., Scaloni, A., Puglia, A. M., \& Gallo, G. (2015). Tryptophan promotes morphological and physiological differentiation in Streptomyces coelicolor. Appl. Microbiol. Biotechnol. 99: 10177-10189. doi:10.1007/s00253-015-7012-4

Paul A. K. \& Banerjee A. K. (1983). Determination of optimum conditions for antibiotic production by Streptomyces galbus. Folia Microbiol. 28: 397-405. doi:10.1007/BF02879489

Pettit, R. K. (2011). Small-molecule elicitation of microbial secondary metabolites. Microbiol. Biotechnol. 4(4): 471-478. doi:10.1111/j.1751-7915.2010.00196.x

Polymenakou, P. (2012). Atmosphere: a source of pathogenic or beneficial microbes? Atmosphere 3: 87-102. doi:10.3390/atmos3010087

Watve, M. G., Tickoo, R., Jog, M. M., \& Bhole, B. D. (2001). How many antibiotics are produced by the genus Streptomyces? Arch. Microbiol. 176: 386-390. doi: $10.1007 / \mathrm{s} 002030100345$

Weber, C. F., \& Werth, J. T. (2015). Is the lower atmosphere a readily accessible reservoir of culturable, antimicrobial compound producing Actinomycetales? Front. Microbiol. 6: 802. doi: 10.3389/fmicb.2015.00802

Weinberg, E. D. (1990). Roles of trace metals in transcriptional control of microbial secondary metabolism. Biol. Metals 2: 191-196. doi:10.1007/BF01141358

World Health Organization [WHO] (2015). Antibiotic Resistance. Retrieved April 25, 2016, from http://www.who.int/mediacentre/factsheets/antibiotic-resistance/en/

Womack, A. M., Bohannan, B. J. M., \& Green J. L. (2010). Biodiversity and biogeography of the atmosphere. Phil. Trans. R. Soc. B 365, 3645-3653. doi:10.1098/rstb.2010.0283

Wright, L. F., \& Hopwood, D. A. (1976). Identification of the antibiotic determined by the SCP1 plasmid of Streptomyces coelicolor A3(2). J. Gen. Microbiol. 95: 96-106.

Yamasaki, S., Furuya, N., \& Matsuyama, N. (1998). Effects of specific ions in agar on antibiotic production by Burkholderia glumae. J. Fac. Agr. 43(3.4): 309-314. 